\title{
Efektivitas Model Problem Based Learning (Pbl) terhadap Hasil Belajar Mahasiswa Prodi Pendidikan Biologi Universitas Sulawesi Barat
}

\author{
Syamsiara Nur*1, Indah Panca Pujiastuti*2, Sari Rahayu Rahman*3 \\ *1,2,3Program Studi Pendidikan Biologi FMIPA Universitas Sulawesi Barat \\ E-mail : nur_syamsiara@yahoo.co.id*1, indah_panca@yahoo.co.id*2, \\ s.rahayu.rahman@gmail.com*3
}

\begin{abstract}
Abstrak
Pembelajaran pada hakikatnya merupakan proses interaksi antara peserta didik dengan lingkungannya, sehingga terjadi perubahan perilaku kearah yang lebih baik. Hasil observasi yang telah dilakukan di Prodi Pendidikan Biologi Universitas Sulawesi Barat (UNSULBAR) pada matakuliah Biokimia, diketahui bahwa hasil belajar kognitif mahasiswa masih rendah, yaitu hampir 80\% mahasiswa mendapat nilai di bawah 60. Salah satu model pembelajaran yang maтри melatih peserta didik dalam mengatasi permasalahan tersebut adalah dengan menerapkan model Problem Based Learning (PBL).

Tujuan penelitian ini adalah untuk mengetahui pengaruh PBL terhadap hasil belajar kognitif mahasiswa pada matakuliah Biokimia Prodi Pendidikan Biologi UNSULBAR. Metode dalam penelitian ini adalah eksperimen semu (quasy experiment), dengan menggunakan dua kelas, yaitu kelas eksperimen (model PBL) dan kelas kontrol (model konvensional). Rancangan dalam penelitian ini yaitu Post-test Only Control Design.

Uji hipotesis dalam penelitian ini menggunakan uji Independent Sample t-Test dengan bantuan program SPSS. Berdasarkan analisis yang telah dilakukan menunjukkan bahwa data hasil belajar kognitif mahasiswa memiliki nilai t hitung sebesar 5,422, derajat kebebasan sebesar 42, signifikansi sebesar 0,000 dan rata-rata perbedaan sebesar 13,636. Melihat nilai signifikansi yang lebih kecil dari 0,05, maka dapat disimpulkan bahwa hipotesis alternatif $\left(H_{1}\right)$ diterima dan hipotesis nol $\left(H_{0}\right)$ ditolak, artinya ada pengaruh penggunaan model pembelajaran PBL terhadap hasil belajar kognitif mahasiswa.
\end{abstract}

Kata Kunci : PBL, hasil belajar kognitif 


\section{PENDAHULUAN}

Pembelajaran pada hakikatnya merupakan proses interaksi antara peserta didik dengan lingkungannya, sehingga terjadi perubahan perilaku kearah yang lebih baik (Mulyasa, 2010). Proses pembelajaran sepenuhnya diarahkan pada pengembangan pada ranah kognitif, afektif, dan psikomotor secara utuh/holistik. Dengan demikian proses pembelajaran secara utuh melahirkan kualitas yang mencerminkan keutuhan penguasaan sikap, pengetahuan, dan keterampilan (Depdiknas, 2013).Pencapaian tujuan pembelajaran ini dapat ditentukan oleh adanya motivasi peserta didik untuk berubah menjadi lebih baik.

Berdasarkan observasi yang telah dilakukan di Prodi Pendidikan Biologi Universitas Sulawesi Barat (UNSULBAR) pada matakuliah Biokimia, diketahui bahwa motivasi dan hasil belajar kognitif mahasiswa masih rendah. Hal ini karena sebagian besar mahasiswa tidak memperhatikan penjelasan dosen pada saat mengajar sertaselalu menunda-nunda waktu saat mengumpulkan tugas. Hasil ujian Biokimia juga sangat rendah, dimana hampir $80 \%$ mahasiswa mendapat nilai di bawah 60 . Hal yang sangat disayangkan bahwa selama ini mahasiswa belum pernah melaksanakan kegiatan eksperimen sehingga belum memberdayakan keterampilan proses sains. Hal ini menyebabkan materi pembelajaran yang telah dipelajari akan cepat dilupakan oleh mahasiswa.

Salah satu model pembelajaran yang mampu melatih peserta didik dalam mengatasi permasalahan-permasalahan tersebut adalah dengan menerapkan model Problem Based Learning (PBL). PBL merupakan pembelajaran yang memfasilitasi peserta didik belajar melalui pemecahan masalah dunia nyata dan autentik serta mengintegrasikan pengetahuan lintas disiplin (Keziah, 2010).Wahyudi (2015) menambahkan bahwa PBL mampu meningkatkan keterampilan proses sains dan hasil belajar peserta didik dibandingkan model konvensional. Istanti (2015) menjelaskan bahwa PBL mampu meningkatkan motivasi belajar peserta didik.

Problem Based Learning (PBL) adalah model pembelajaran yang mendorong peserta didik untuk mengenal cara belajar dan bekerjasama dalam kelompok untuk mencari penyelesaian masalah-masalah di dunia nyata (Akcay, 2009). PBL mempunyai kemampuan untuk melatih peserta didik dalam menemukan konsepnya sendiri berdasarkan masalah nyata dari kehidupan dengan keterampilan penyelidikan sehingga model tersebut merupakan model yang paling tinggi levelnya (Mugla, 2011).

Yuan (2008) menyatakan bahwa PBL adalah model pembelajaran yang berpusat pada peserta didik untuk belajar, memungkinkan berpartisipasi, dan menghadapi situasi pemecahan dalam kerja kelompok kecil selama proses pembelajaran.Menurut Muhson (2009), PBL merupakan metode belajar yang menggunakan masalah sebagai langkah awal dalam mengumpulkan dan mengintegrasikan pengetahuan baru. Menurut Keziah (2010), PBL merupakan pembelajaran yang memfasilitasi peserta didik belajar melalui pemecahan masalah dunia nyata dan autentik serta mengintegrasikan pengetahuan lintas disiplin.

Arends (2009) mengemukakan sintaks PBL yang berhubungan dengan kegiatan pendidik seperti pada Tabel 1. 
Tabel 1 Sintaks Model PBL

\begin{tabular}{|l|l|}
\hline \multicolumn{1}{|c|}{ Tahap } & \multicolumn{1}{c|}{ Kegiatan Pendidik } \\
\hline $\begin{array}{l}\text { Tahap 1: Melakukan } \\
\text { orientasi masalah kepada } \\
\text { peserta didik }\end{array}$ & $\begin{array}{l}\text { Pendidik menjelaskan tujuan pembelajaran, menjelaskan } \\
\text { logistik(bahan dan alat) apa yang dibutuhkan bagi penyelesaian } \\
\text { masalah, sertamemotivasi peserta didik untuk terlibat dalam } \\
\text { pemecahan masalah yang dipilih }\end{array}$ \\
\hline $\begin{array}{l}\text { Tahap 2: } \\
\text { Mengorganisasikan peserta } \\
\text { didik untuk belajar }\end{array}$ & $\begin{array}{l}\text { Pendidik membantu peserta didik untuk mendefinisikan tugas } \\
\text { belajar yang berhubungan dengan masalah tersebut }\end{array}$ \\
\hline $\begin{array}{l}\text { Tahap 3: Membimbing } \\
\text { kelompok investigasi }\end{array}$ & $\begin{array}{l}\text { Pendidik mendorong peserta didik untuk mengumpulkan } \\
\text { informasi yang sesuai,melaksanakan eksperimen untuk } \\
\text { mendapatkan penjelasan dan pemecahan masalah }\end{array}$ \\
\hline $\begin{array}{l}\text { Tahap 4: Mengembangkan } \\
\text { dan menyajikan hasil } \\
\text { karya }\end{array}$ & $\begin{array}{l}\text { Pendidik membantu peserta didikdalam merencanakan dan } \\
\text { menyiapkan karya yang sesuai dengan tugas yang diberikan, } \\
\text { seperti laporan, video, dan model serta membantu mereka untuk } \\
\text { berbagi tugas dengan temannya. }\end{array}$ \\
\hline $\begin{array}{l}\text { Tahap 5: Menganalisis dan } \\
\text { mengevaluasi proses } \\
\text { pemecahan masalah }\end{array}$ & $\begin{array}{l}\text { Pendidik membantu peserta didik untuk melakukan refleksi } \\
\text { atau evaluasi terhadap hasil penyelidikannya, serta proses-proses } \\
\text { pembelajaran yang telah dilaksanakan. }\end{array}$ \\
\hline
\end{tabular}

Kelebihan dan kelemahan PBL menurut Warsono dan Hariyanto (2013) antara lain:

1. Kelebihan:

a. Peserta didik akan terbiasa menghadapi masalah dan merasa tertantang untuk menyelesaikan masalah, tidak hanya terkait dengan pembelajaran dalam kelas, tetapi juga dalam kehidupan sehari-hari.

b. Memupuk solidaritas social dengan terbiasa berdiskusi dengan teman-teman sekelompok kemudian berdiskusi dengan teman-teman sekelasnya.

c. Makin mengakrabkan pendidik dengan peserta didik.

d. Membiasakan peserta didik dalam menerapkan metode eksperimen.

2. Kelemahan:

a. Tidak banyak pendidik yang mampu mengantarkan peserta didik kepada pemecahan masalah.

b. Seringkali memerlukan biaya mahal dan waktu yang panjang.

c. Aktivitas peserta didik yang dilaksanakan di luar kelas sulit dipantau oleh pendidi

Hasil belajar merupakan perubahan perilaku yang diperoleh pembelajar setelah mengalami aktivitas belajar. Hasil belajar hanya bisa diperoleh seseorang setelah melaksanakan aktivitas belajar (Rifa'I dan Anni, 2011). Lapono (2008) menambahkan bahwa hasil belajar menjadikan perubahan tingkah laku sebagai indikator seseorang memperoleh hasil belajar atau tidak. Hasil belajar diukur berdasarkan terjadi atau tidaknya perubahan tingkah laku pada diri seseorang yang telah melaksanakan proses belajar. 
Hasil belajar pada diri seseorang menurut Bloom dalam Pujiastuti (2013) meliputi tiga ranah, yaitu ranah kognitif, afektif, dan psikomotor. Hasil belajar kognitif meliputi:mengingat (remember), memahami (understand), menerapkan (apply), menganalisis (analyze), mengevaluasi (evaluate), dan mencipta (create).Menurut Arikunto (2013), hasil belajar peserta didik dinilai melalui pemberian tes, di mana tes dibedakan menjadi dua bentuk yaitu tes subjektif dan tes objektif.

Berdasarkan uraian yang telah dijelaskan, maka peneliti melakukan penelitian dengan judul: "Efektivitas Model Problem Based Learning (PBL) terhadap Hasil Belajar Mahasiswa Prodi Pendidikan Biologi UNSULBAR".

\section{METODE PENELITIAN}

Jenis penelitian ini adalah penelitian eksperimen semu (quasy experiment) karena subjek penelitian telah ditentukan (tidak secara random/acak), dimana setiap subjek memperoleh peluang sama untuk dijadikan subjek penelitian. Rancangan penelitian yang digunakan dalam penelitian ini adalah non equivalent control group design, dengan menggunakan dua kelas, yaitu kelas eksperimen (model PBL) dan kelas kontrol (model konvensional). Penelitian ini akan dilaksanakan di Prodi Pendidikan Biologi, Universitas Sulawesi Barat, yang terletak di jalan Baharuddin Lopa, SH. Lutang, Majene. Penelitian akan dilaksanakan pada bulan Agustus-September 2016.

Populasi dalam penelitian ini adalah mahasiswa Prodi Pendidikan Biologi semester III UNSULBAR tahun pelajaran 2016/2017. Sampel dalam penelitian ini adalah kelas B sebagai kelas eksperimen dan kelas A sebagai kelas kontrol. Jumlah mahasiswa di kelas A adalah 24 dan dikelas B berjumlah 25 mahasiswa.

Beberapa variabel dalam penelitian ini dapat dijabarkan sebagai berikut.

1. Variabel bebas : Problem Based Learning (PBL)

2. Variabel terikat : hasil belajar kognitif mahasiswa

3. Variabel kontrol : materi pembelajaran dan instrumen tes

Instrumen yang digunakan dalam penelitian ini adalah sebagai berikut:

1. Soal tes untuk hasil belajar dan retensi belajar mahasiswa, berupa soal-soal pilihan ganda dan uraian.Data retensi mahasiswa diperoleh dari tes tertulis yang dilakukan dua minggu setelah postest.

2. Lembar observasi kegiatan dosen, digunakan untuk mengamati keterlaksanaan kegiatan pembelajaran yang sesuai dengan sintaks pembelajaran PBL.

3. Angket respon mahasiswa, digunakan untuk mengetahui pendapat mahasiswa tentang keterlaksanaan kegiatan pembelajaran yang telah dilaksanakan.

Prosedur dalam penelitian ini meliputi tahap persiapan, pelaksanaan, dan publikasi. Adapun tahapan-tahapannya adalah sebagai berikut.

1. Tahap persiapan, meliputi:

a. Melakukan observasi ke Prodi Pendidikan Biologi UNSULBAR tentang kondisi mahasiswa di kelas pada saat pembelajaran berlangsung

b. Menyusun Satuan Acara Perkuliahan (SAP) pada materi perkuliahan uji karbohidrat, bahan ajar, dan instrumen penelitian. 
c. Melakukan analisis uji butir soal, berupa uji validitas dan reliabilitas soal-soal tes yang akan digunakan untuk mengukur hasil belajar dan retensi mahasiswa.

2. Tahap pelaksanaan, dilaksanakan sesuai dengan tahap model PBL, yaitu:

a. Pelaksanaan pre test

b. Melakukan orientasi masalah kepada mahasiswa

c. Mengorganisasikan mahasiswa untuk belajar

d. Membimbing kelompok investigasi

e. Mengembangkan dan menyajikan hasil karya

f. Menganalisis dan mengevaluasi proses pemecahan masalah

g. Pelaksanaan post test

3. Tahap analisis data, yaitu menganalisis hasil belajar.

\section{HASIL DAN PEMBAHASAN}

\section{Deskripsi Data}

Data hasil belajar kognitif mahasiswa pada kelas eksperimen diperoleh dari hasi lpost-tes setelah diberikan perlakuan dengan menggunakan model pembelajaran PBL. Adapun di kelas kontrol menggunakan pembelajaran konvensional dengan metode ceramah dan tanya-jawab. Data hasil distribusi frekuensi post-tes kelas eksperimen dan kelas kontrol disajikan pada Tabel 2.

Tabel 2 Distribusi Frekuensi Hasil Belajar Kognitif

\begin{tabular}{ccccc}
\hline & \multicolumn{2}{c}{ Kelas Eksperimen } & \multicolumn{2}{c}{ Kelas Kontrol } \\
\hline No & Kelas Interval & Frekuensi & Kelas Interval & Frekuensi \\
\hline 1 & $60-64$ & 3 & $45-49$ & 2 \\
2 & $65-69$ & 2 & $50-54$ & 5 \\
3 & $70-74$ & 5 & $55-59$ & 0 \\
4 & $75-79$ & 4 & $60-64$ & 6 \\
5 & $80-85$ & 8 & $65-69$ & 6 \\
6 & $86-90$ & 0 & $70-75$ & 3 \\
\hline
\end{tabular}

Dari Tabel Tabel 3.1, dapat diketahui bahwa pada kelas eksperimen, frekuensi terbanyak berada pada kisaran interval 80 sampai 85. Sedangkan pada kelas kontrol, frekuensi terbanyak berada pada kisaran 60 sampai 69.Nilai rata-rata post-test siswa pada kelas eksperimen sebesar 73, sedangkan nilai rata-rata post-test siswa pada kelas control sebesar 60.Untuk memberikan gambaran yang jelas, maka distribusi frekuensi hasil belajar kognitif mahasiswa ditampilkan dalam bentuk histogram seperti pada Gambar 1 dan Gambar 2. 


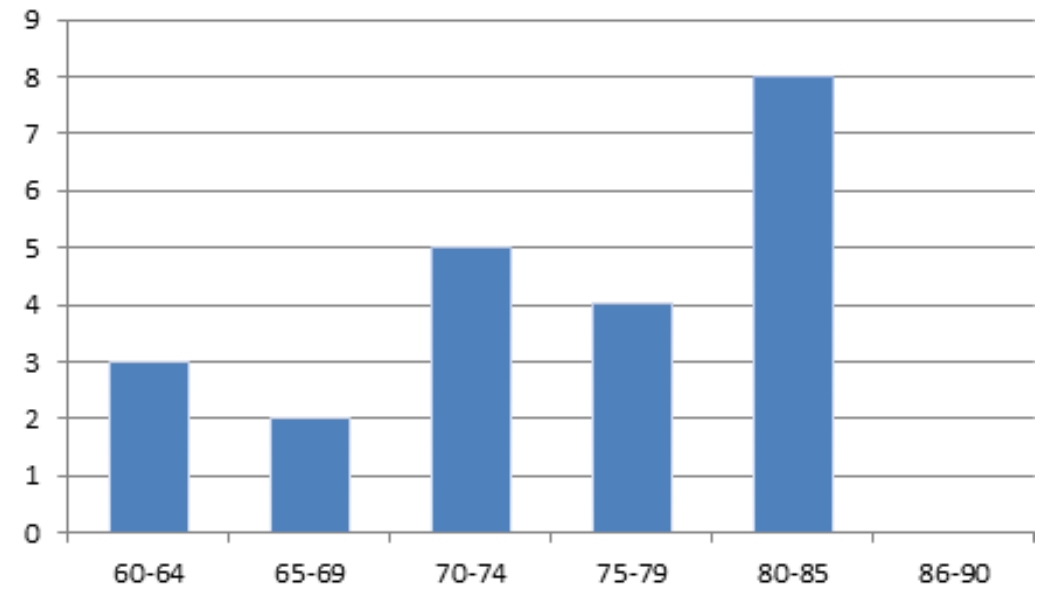

Gambar 1. Histogram Data Hasil Distribusi Frekuensi Post-tes Kelas Eksperimen



Gambar 2. Histogram Data Hasil Distribusi Frekuensi Post-tes Kelas Kontrol

\section{Uji Prasyarat (Uji Normalitas dan Uji Homogenitas)}

Data yang didapatkan kemudian diuji normalitas untuk mengetahui apakah variabelvariabel dalam penelitian mempunyai sebaran distribusi normal atau tidak.Uji normalitas untuk data hasil belajar kognitif mahasiswa menggunakan uji Shapiro-Wilk dengan bantuan program SPSS for windows versi 16. Pedoman untuk pengambilan keputusan dalam uji normalitas adalah jika nilai sigifikan lebih besar dari level kepercayaan $(\dot{\alpha}=0,05)$ maka data tersebut terdistribusi normal. Hasil uji normalitas untuk data hasil belajar kognitif mahasiswa disajikan pada Tabel 3. 
Tabel 3 Hasil Uji Normalitas Data Hasil Belajar Kognitif Mahasiswa

\begin{tabular}{cccc}
\hline \multirow{2}{*}{ Kelas } & \multicolumn{3}{c}{ Kolmogorov-Smirnov } \\
\cline { 2 - 4 } & Statistik & Df & Sig. \\
\hline Eksperimen & 0,921 & 22 & 0,081 \\
Kontrol & 0,918 & 22 & 0,069 \\
\hline
\end{tabular}

Dari Tabel 2, dapat diketahui bahwa sebaran data hasil belajar kognitif di kelas eksperimen sebesar 0,081, sedangkan sebaran data hasil belajar kognitif di kelas control sebesar 0,069. Melihat nilai signifikansi data hasil belajar kognitif di kelas eksperimen dan kelas kontrol yang lebih besar dari level kepercayaan $(\dot{\alpha}=0,05)$, maka dapat dikatakan bahwa semua datanya berdistribusi normal.

Selanjutnya data yang didapatkan juga diuji homogenitas untuk mengetahui apakah sampel yang diambil memiliki varian yang sama atau tidak menunjukkan perbedaan yang signifikan satu sama lain. Uji homogenitas dalam penelitian ini menggunakan uji Levene's Test of Equality of Error Variances dengan bantuan program SPSS for windows versi 16.

Pedoman untuk pengambilan keputusan dalam uji homogenitas yaitu, jika nilai sigifikan lebih besar dari level kepercayaan $(\dot{\alpha}=0,05)$ maka data tersebut dikatakan homogen, namun sebaliknya jika nilai sigifikan lebih kecil dari level kepercayaan $(\dot{\alpha}=0,05)$ maka data tersebut dikatakan tidak homogen. Hasil uji homogenitas untuk data hasil belajar kognitif disajikan pada Tabel 4.

Tabel 4. Hasil Uji Homogenitas Data Hasil Belajar Kognitif Mahasiswa

\begin{tabular}{cccccc}
\hline Data & Levene Statistic & df1 & df2 & Sig. \\
\hline HasilBelajarKognitif & 0,105 & & 1 & & 42 \\
\hline
\end{tabular}

Dari Tabel 4, dapat diketahui bahwa data hasil belajar kognitif mahasiswa memiliki nilai signifikansi sebesar 0,748. Melihat nilai signifikansi hasil belajar kognitif yang lebih besar dari level kepercayaan $(\alpha=0,05)$, maka dapat dikatakan bahwa kelas yang diajar dengan menggunakan model pembelajaran PBL dan kelas yang diajar dengan menggunakan pembelajaran konvensional dengan metode ceramah dan tanya-jawab, memiliki variansi yang sama (homogen).

\section{Uji Hipotesis}

Uji hipotesis dilakukan untuk menguji ada tidaknya pengaruh penggunaan model pembelajaran PBL terhadap hasil belajar kognitif mahasiswa.Uji hipotesis dalam penelitian ini menggunakan uji Independent Sample t-Test dengan bantuan program SPSS for windows versi 16.Pengambilan keputusan uji hipotesis yaitu jika nilai sig. $<0,05$, maka hipotesis $\mathrm{H}_{0}$ ditolakdan $\mathrm{H}_{1}$ diterima. Jika nilai sig. $>0,05$, maka hipotesis $\mathrm{H}_{0}$ diterima dan $\mathrm{H}_{1}$ ditolak. Ringkasan hasil uji Independent Sample t-Test terhadap hasil belajar mahasiswa pada kelas eksperimen dan kelas kontrol disajikan dalam Tabel 4. 
JURNAL SAINTIFIK VOL.2 NO.2, JULI 2016

Tabel 5. Ringkasan Uji Independent Sample t-Test Terhadap Hasil Belajar Kognitif

\begin{tabular}{lrrccc}
\hline & \multicolumn{5}{c}{ t-test for Equality of Means } \\
\cline { 2 - 6 } & $\mathbf{t}$ & \multirow{2}{*}{ df } & $\begin{array}{c}\text { Sig. (2- } \\
\text { tailed) }\end{array}$ & $\begin{array}{c}\text { Mean } \\
\text { Difference }\end{array}$ & $\begin{array}{l}\text { Std. Error } \\
\text { Difference }\end{array}$ \\
\hline $\begin{array}{l}\text { Equal variances } \\
\text { assumed }\end{array}$ & 5,42 & \multirow{2}{*}{42} & 0,000 & 13,63636 & 2,51520 \\
\hline
\end{tabular}

Tabel 5 menunjukkan bahwa data hasil belajar kognitif mahasiswa memiliki nilai $\mathrm{t}$ hitung sebesar 5,422, derajat kebebasan sebesar 42, signifikansi sebesar 0,000 dan rata-rata perbedaan sebesar13,636. Melihat nilai signifikansi yang lebih kecil dari 0,05, maka dapat disimpulkan bahwa hipotesis alternative $\left(\mathrm{H}_{1}\right)$ diterima dan hipotesis nol $\left(\mathrm{H}_{0}\right)$ ditolak, artinya ada pengaruh penggunaan model pembelajaran PBL terhadap hasil belajar kognitif mahasiswa.

Hasil belajar merupakan perubahan perilaku yang diperoleh pembelajar setelah mengalami aktivitas belajar.Hasil belajar hanya bisa diperoleh seseorang setelah melaksanakan aktivitas belajar (Rifa'IdanAnni, 2011).Hasil uji t di atas menunjukkan bahwa ada pengaruh model PBL terhadap hasil belajar.Hasil uji t ini sejalan dengan penelitian yang telah dilakukan oleh Febriyani, R. 2013, dengan judul keefektifan PBL terhadap hasil belajar siswa. Hasil penelitian ini adalah ada pengaruh model PBL terhadap hasil belajar, dengan hasil rerata kelompok eksperimen yaitu 80,45, sedangkan kontrol yaitu 72,39.

\section{KESIMPULAN}

Kesimpulan dalam penelitian ini adalah ada pengaruh penggunaan model pembelajaran PBL terhadap hasil belajar kognitif mahasiswa. Hasil belajar merupakan perubahan perilaku yang diperoleh pembelajar setelah mengalami aktivitas belajar.

\section{DAFTAR PUSTAKA}

Akcay, B. 2009. Problem-Based Learning in Science Education. Journal of Turkish Science Education. Vol. 6, No. 1.

Arends, R.I. 2009. Learning to Teach. Boston: McGraw-Hill International Ed.

Arikunto, S. 2013. Dasar-Dasar Evaluasi Pendidikan. Jakarta: Bumi Aksara.

Chen, dkk. 2008. Conceptualizing engagement: Contributions of Faculty to Student Engagement in Engineering. Journal of Engineering Education. Vol.93, No. 3.

Crosling, dkk. 2009. Improving Student Retention in Higher Education: Improving Teaching and Learning. Australian Universities Review. Vol. 53, No. 2.

Depdiknas. 2013. Permendikbud Nomor 66 tahun 2013 tentang Standar Penilaian Pendidikan. Jakarta: Depdiknas.

Dimyati dan Mudjiono. 2009. Belajar dan Pembelajaran. Jakarta: Rineka Cipta.

Dunlosky, J. \& Rawson, K.A. 2012. Overconfidence Produces Under-achievement: Inaccurate Selt Evaluations Undermine Students' Learning and Retention. Elsevier Journal. Vol. 22, No. 1. 
Febriyani, R. 2013. Keefektifan Problem Based Learning terhadap Aktivitas dan Hasil Belajar Siswa Kelas IV Sekolah Dasar Negeri 1 Dagan Kabupaten Purbalingga pada Materi Globalisasi. Skripsi tidak diterbitkan. Semarang: Universitas Negeri Semarang.

Hamalik, O. 2011. Perencanaan Pengajaran berdasarkan Pendekatan Sistem. Jakarta: Bumi Aksara.

Hergenhahn, B.R. dan Olson, M.H. 2008. Theories of Learning (Teori Belajar). Terjemahan oleh Tri Wibowo. Jakarta: Kencana.

Keziah, A. A. 2010. A Comparative Study of Problem-Based and Lecture-Based Learning in Secondary School Students' Motivation to Learn Science. International Journal of Science and Technology Education Research. Vol. 1, No. 6.

Masek, A. \& Sulaiman, Y. 2011. The Effect of Problem Based Learning on Critical Thinking Ability: A Theoretical and Empirical Review. International Review of Social Sciences and Humanities. Vol. 2, No. 1.

Mugla. 2011. Overviews on Inquiry Based and Problem Based Learning methods. Journal of Educational Science. ISSN: 1308-8971.

Muhson, A. 2009. Peningkatan Minat Belajar dan Pemahaman Mahasiswa Melalui Penerapan Problem-Based Learning. Jurnal Kependidikan. Vol.39, No. 2.

Mulyasa, E. 2010. Kurikulum Tingkat Satuan Pendidikan. Bandung: PT. Remaja Rosda Karya.

Rustaman, dkk. 2007. Strategi Belajar Mengajar Biologi. Malang: UM Press.

Sardiman, A. M. 2011. Interaksi dan Motivasi Belajar Mengajar. Jakarta: Remaja Press.

Sukmadinata, N.S. 2011. Metode Penelitian Pendidikan. Bandung: PT Remaja Rosdakarya.

Pujiastuti, I.P. Penerapan Integrasi Model Pembeljaran Group Investigation (GI) dan Inkuiri Terbimbing Berbasis Lesson Study untuk Meningkatkan Keterampilan Kerja Ilmiah dan Hasil Belajar Biologi Siswa Kelas X-IPA 1 MA Negeri 3 Malang. Laporan PPL. Malang: PPs UM.

Warsono dan Harianto. 2013. Pembelajaran Aktif. Bandung: Remaja Rosdakarya.

Wicaksono, A.G.C. dan Corebima, A.D. 2015. Hubungan Antara Keterampilan Metakognitif dan Retensi Siswa dalam Strategi Reciprocal Teaching Dipadu Jigsaw di Kelas X SMAN 7 Malang. Jurnal Bioma. Vol. 4, No. 1.

Yuan, H., dkk. 2008. Promoting Critical Thinking Skills Through Problem-Based Learning. Journal of social Science and Humanities. Vol. 2, No.2.

Zulfiani, dkk. 2009. Strategi Pembelajaran Sains. Jakarta: Lembaga Penelitian UIN Jakarta. 